Eesti Arheoloogiaajakiri, 2004, 8, 1, 33-48

Jussi-Pekka Taavitsainen

\title{
A KISTEN FROM MULLI, RAISIO - A MANIFESTATION OF MIDDLE EUROPE IN SOUTHWESTERN FINLAND
}

This article presents the Raisio project of the Department of Archaeology of the School of Cultural Reseach at the University of Turku. The excavations of the project revealed an unusual find of eastern provenance, a kisten ball from a strap flail or lash. The use and distribution of this weapon type in Northern Europe is discussed. The find also serves to demonstrate the so-called Middle Europe as a transitional zone between the eastern and western cultural spheres, and some problems of the formation of cultural boundaries and intermediate zones lying between them.

Tutvustatakse Turu Ülikooli arheoloogia õppetooli Raisio projekti, mille raames toimunud väljakaevamistel avastati ebaharilik idapoolse päritoluga leid - piitsnuia munak. Arutletakse selle relvatüübi kasutuse ja leviku üle Põhja-Euroopas. Leiu põhjal näidatakse Kesk-Euroopat kui siirdevööndit ida ja lääne kultuuriareaali vahel ning käsitletakse kultuuripiiride ja vahevööndite kujunemise probleeme.

Jussi-Pekka Taavitsainen, School of Cultural Research/Archaeology, Juslenia, Henrikinkatu 2, FIN-20014 University of Turku; justaa@utu.fi

The Department of Archaeology of the School of Cultural Research at the University of Turku has collaborated with the City of Raisio since 1986, in which connection the archaeological remains of the Ihala section of Raisio were surveyed and inventoried. In 1987-1991, the excavations of the rich Viking Age (800-1025) cremation cemetery of Siiri in Ihala were conducted as a joint project. In 1994-1997 fieldwork was carried out at the Late Iron Age and early medieval dwelling site of Mulli in Ihala. This project was also utilized in a museological context (Harjula \& Ermala 1997; Pihlman \& Ermala 1997; Näränen \& Heikkinen 2000; Näränen 2000), and was associated with a joint project with the University of Art and Design of Helsinki, which was financed by the Academy of Finland. In the latter project new digital technology was applied in the popularization of the results of archaeological research (Díaz 1998a and 1998b; Díaz-Kommonen 2002). The project also involved, and still does, active cooperation with natural sciences. 
The Ihala area was ideally representative for research providing a location and setting rich in finds which had been surveyed in detail. In addition, of the burial grounds in the area the Siiri cremation cemetery had been completely excavated. The partly destroyed cremation cemetery of Kansakoulumäki in Ihala had been excavated at the turn of the 1950s and 1960s (Hirviluoto 1973). The dwelling site chosen for fieldwork in 1994 was in many ways complementary to the previous cemetery excavations. Ms. Sirkku Pihlman $\mathrm{PhD}$ was responsible for directing and organising the research. These studies have served to make archaeology a natural aspect of museum work, local-heritage activities and educational pursuits in Raisio (Pihlman 2000).

The fieldwork continued until 1997. As a result, a total area of approximately $620 \mathrm{~m}^{2}$ was excavated. Late Iron Age and early medieval finds were recovered from an area of ca. $300 \mathrm{~m}^{2}$. The excavation results were surprising. The revealed building remains of the 11th-13th centuries were exceptionally well preserved for Finnish conditions (Vuorinen 1997). The remains appear to have been protected against the effects of deep ploughing by the stone foundation of a farmhouse that was presumably in use in the 18th century. The excavations retrieved a representative and diverse collection of finds.

The excavations at Mulli and previous fieldwork in Raisio provided a basis for the Raisio project, which became part of the project From Village to Town: Changing Lifeways in Southwestern Finland from the 10th to the 16th Century, jointly organised by the Department of Archaeology at the University of Turku and the Turku Provincial Museum, and funded by the Academy of Finland. This research project investigates the ways in which the prerequisites and main factors of community life may have changed or survived as the town of Turku emerged in the late 13th century as a new structure in the area of a recently Christianized community (Pihlman et al. 2001).

During the period under study, the Raisio region became integrated as part of the uniform ideological and economic culture of medieval Finland, the Baltic region and Western Europe as a whole. The terminus of this course of development is aptly expressed by the stone church of Raisio, built ca. 1500-1520 (Hiekkanen 2003, 62). All in all, the Raisio project undertakes to explicate how the local peasant community lived and reacted to both external and internal pressure for change and adaptation, and how this pressure was manifested in the community's reactions to material culture, everyday technology, means of livelihood and the landscape (for further details on the project, see http://www.mlab.uiah.fi/Mulli/e_index.html; on antiquities in Raisio, see Brusila 1992; Spoof 2001; Näränen \& Heikkinen 2000).

The project has already yielded a number of publications (Alén 2001; Díaz 1998a \& 1998b; Jäkärä 1997b \& 1998; Lavento \& Suhonen 2003; Suhonen 1998 \& 2000b; Suhonen \& Vuorinen 1997; Vuorinen 1997 \& 2003b), graduate theses in archaeology (Jäkärä 1997a; Alén 1998; Antell 1998; Tupala 1999; Suhonen 2000a; Spoof 2001; Lehtonen 2003) and quaternary geology (Laakso 1998; Siiro 1998), a licentiate's thesis in archaeology (Vuorinen 2003a) and a doctorate at the University of Art and Design of Helsinki (Díaz-Kommonen 2002) with related web pages (http://www.mlab.uiah.fi/Mulli/e_index.html). The project continues as a wide range of research on the acquired materials. 
Fig. 1. Lash-ball or kisten discovered in the excavation of the Mulli site in Raisio (TYA 631: 190). Photo by: Jari Näränen, Raision museo- ja kulttuurikeskus Harkko.

Joon 1. Raisio Mulli asulakohalt leitud piitsnuia munak.

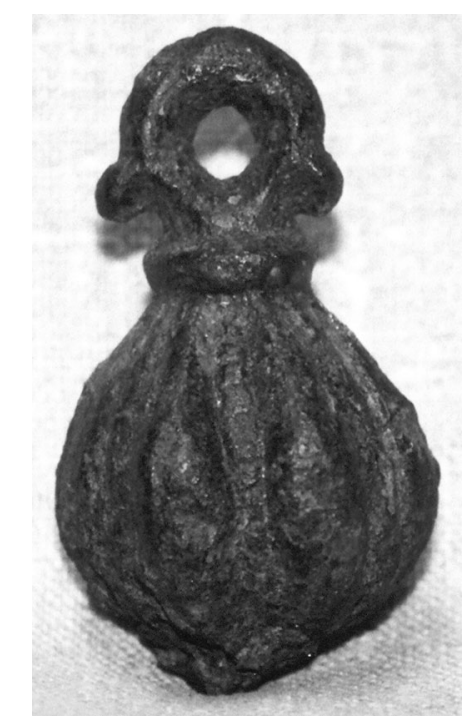

Individual finds have also been presented, of which the most important item is a bronze ingot weighing 16 kilograms and 250 grams (Suhonen 1998). One of the most unexpected finds of the excavations was a bronze object of a pear or onion shape, fitted with a suspension loop and resembling a weight (TYA 631: 190). The object is 6.4 centimetres long with a maximum width of $3.6 \mathrm{~cm}$ and weighs roughly 110 grams. The onion-shaped part is divided into six vertical bulges, between which are narrow zones divided into approximately 2 -millimetre parts with horizontal lines. There is also a bulge in the bottom part and a hole approximately 2 millimetres wide. In the upper part there is a horizontal band-like thickening. The suspension ring is $19 \mathrm{~mm}$ wide on the outside and 6-7 $\mathrm{mm}$ on the inside. On the sides of the ring are lily-shaped leaflet motifs pointing downwards (Fig. 1).

The object is a lash-ball, belonging to a flail weapon consisting of a wooden handle and a ball attached to it with a leather strap or chain (Mäesalu 1998). This type of lash was a common weapon in early medieval Russia, where it was known as the kisten. The weaponry scholar Ain Mäesalu (1998) also refers to it as a jointed, strap or chain flail. This weapon was used by both foot soldiers and cavalry, though it was preferred more by the latter (Fig. 2).

Summarized in the following are the views of A. N. Kirpičnikov regarding the distribution and age of the kistens (Kirpičnikov 1966, 58-65, 134-139; on the kistens found in Novgorod, see Artem'ev 1990). According to him, the oldest kistens were used by the southeastern nomads of the Lower Volga and Don between the 5th and 10 th centuries $\mathrm{AD}$. The weapon was adopted from them into Russia in the 10th century. By 1966, a total of 127 kistens dating from the 9th-13th centuries had been found in the territory of Old Rus'.

Kirpičnikov classes the kistens into six main types (Fig. 3). The oldest are the bone kistens from the 10th-11th centuries; only a few lash balls are known from these centuries. During the following two centuries, smaller and more effective metal 


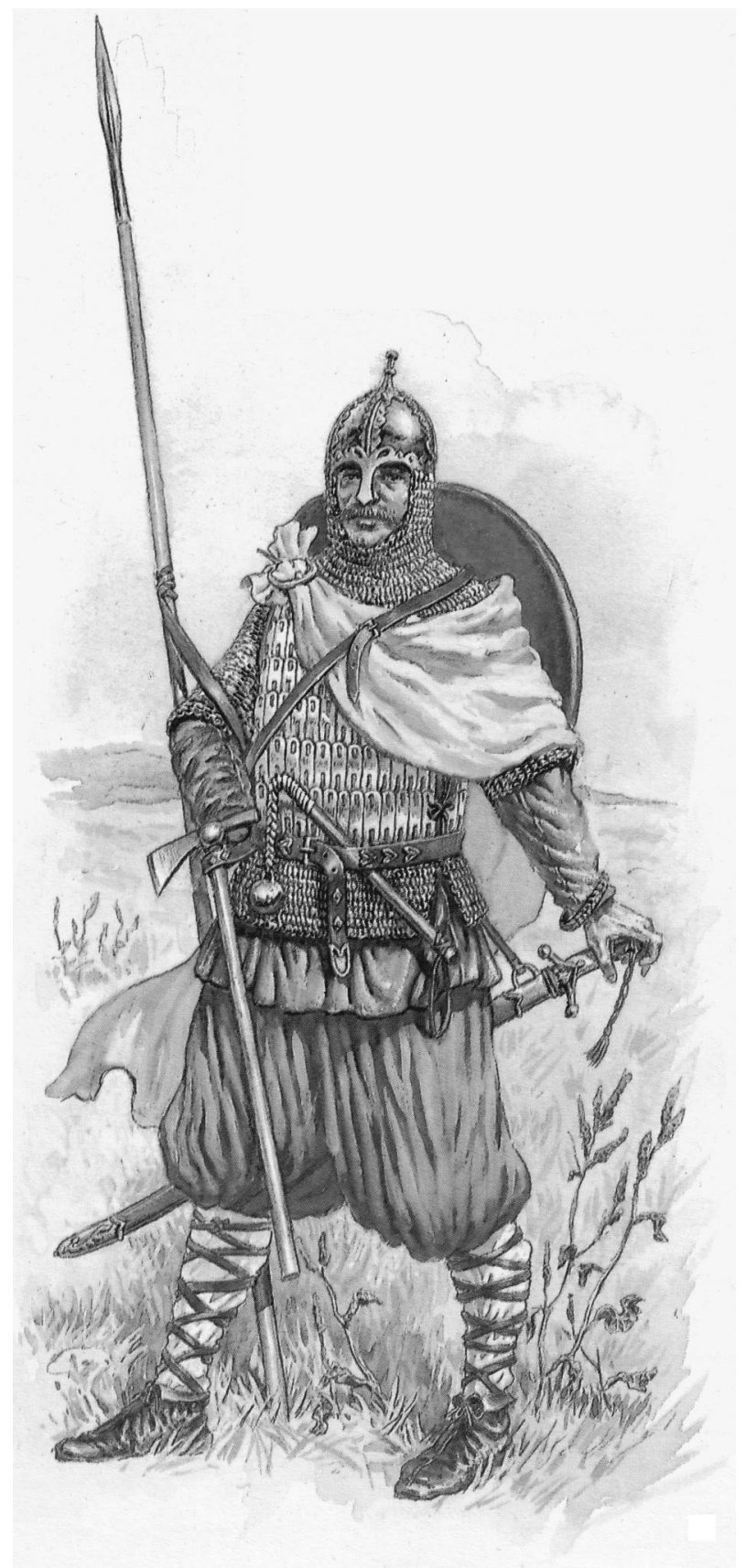

Fig. 2. A druzhina mounted soldier of Kievan Rus, from the mid-10th century or slightly earlier than the Raisio kisten find. According to M. Gorelik (1993). Note the flail with a spiked ball pushed between the belt and the armour.

Joon 2. Kiievi-Vene družiina ratsasõdur 10. sajandi keskpaigast, seega natuke varasemast ajast kui Mulli piitsnui. Jälgi nakkidega varustatud munakuga piitsnuia sõjamehe vööl. 


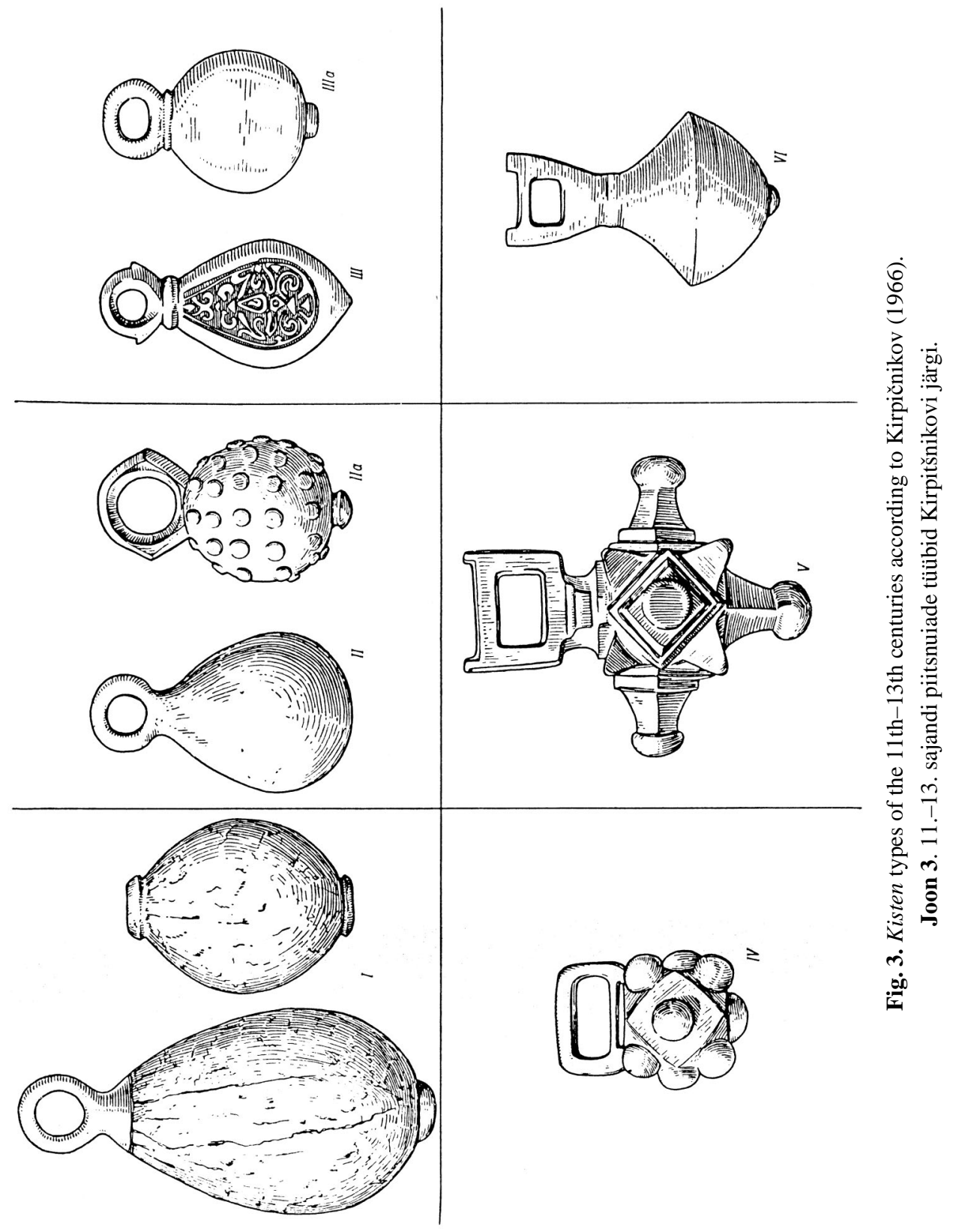


kistens, which were more durable than the bone ones, were introduced. Those came into common use in the territory of Russia and there they also achieved their widest distribution (Fig. 4).

There are also a few early written references to the weapon; it is depicted in the Radziwil Chronicle in an illustration of the killing of Igor Olgovitsha (1147) and in

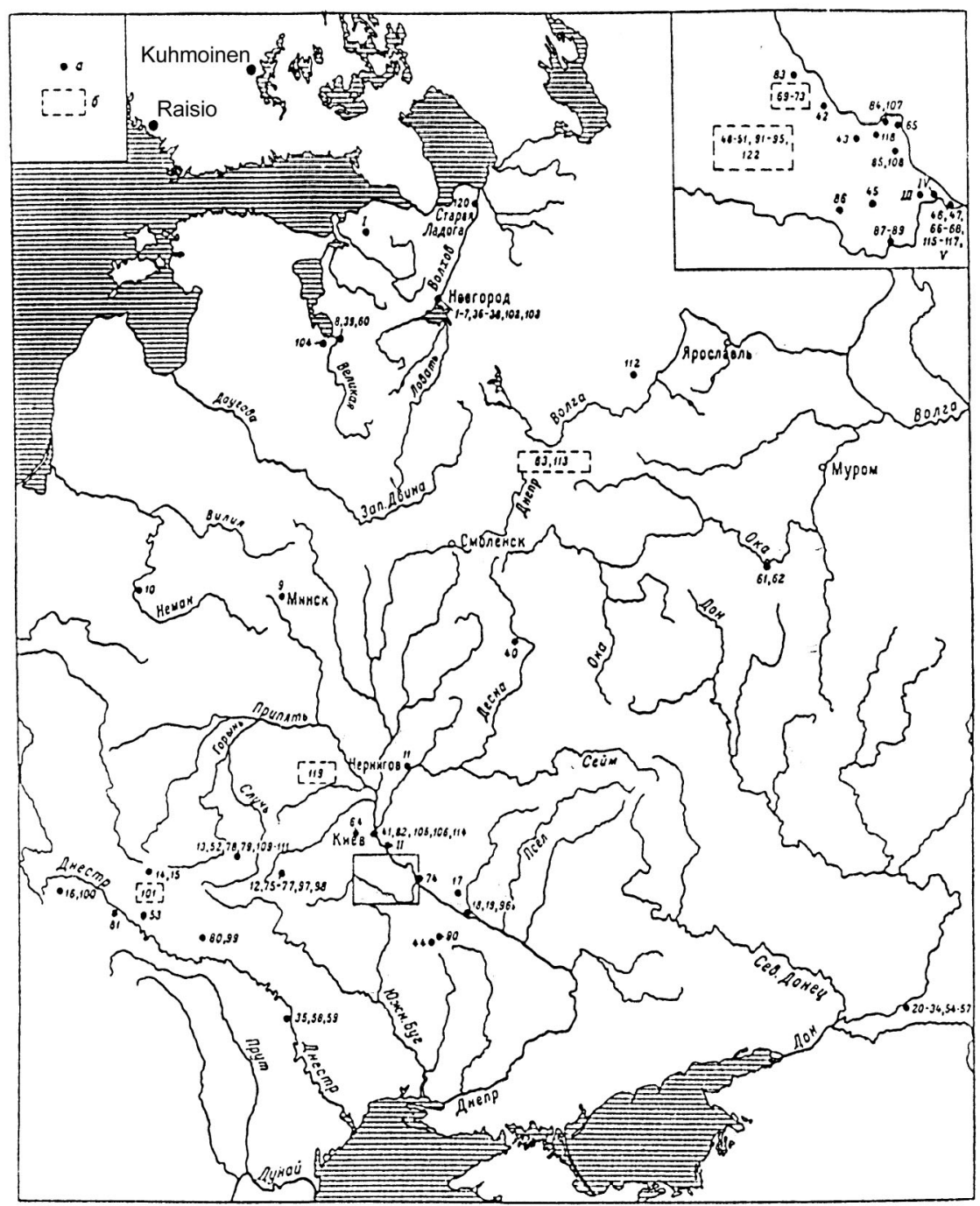

Fig. 4. Kirpičnikov's (1966) distribution map with the Finnish finds added. A kisten of Type III has been found in Mainz, Germany, outside the area shown in the map.

Joon 4. Kirpitšnikovi koostatud piitsnuiade levikukaart, kuhu on lisatud Soome leiud. Saksamaalt Mainzist leitud III tüübi piitsnuia otsik on väljaspool kaardil kujutatud ala. 
Fig. 5. Kisten from Volzhkaya Bolgariya dated to the 13th century (Kirpičnikov 1976).

Joon 5. Volga-Bulgaariast leitud 13. sajandi piitsnuia munak.

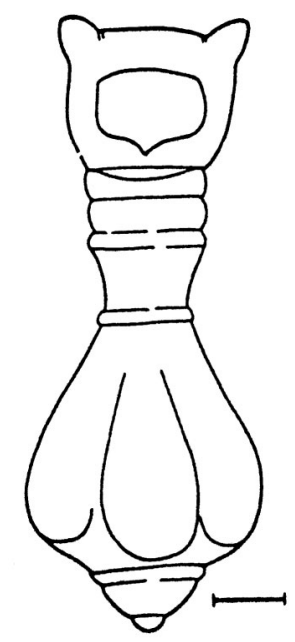

two sources from the 16th century. The weapon type remained long in use, as is also indicated by some related items of oral tradition.

Kirpičnikov's table of types does not contain any exact parallels to the Mulli type, but a kisten closely resembling it has been found at Volzhkaya Bolgariya (Fig. 5), being dated to the 13th century (Kirpičnikov 1976, 27).

Mäesalu (1998) underlines that he has no definite information either from Estonia or Western Europe regarding jointed flails of the 10th-14th centuries. There is, however, another find of a kisten from Finland. It was excavated at the Kuhmoinen hillfort (Taavitsainen 1990, 191-193). It belongs to Kirpičnikov's Type II: smooth or knobbed metal kistens of globular or pear shape (Fig. 3). Globular, knobbed flail ends form Group IIa, among which are directly identical specimens (e.g. kisten No. 69 from Kiev oblast, Kirpičnikov 1966: Table XXXI: 6). This group is dated to the 12th-13th centuries and a total of 22 specimens of it are known, mainly from the towns of Southern and Northwestern Russia, particularly Kiev, where almost half of all finds of the type have been recovered (Kirpičnikov 1966, 64, Table 15). It has been suggested that the town had the privilege of making and distributing kistens. Many of them obviously come from the same workshops.

In addition to Types IV and VI, IIa belongs to the kisten types that spread outside Russia to the territory of the Volga Bolgars. Kirpičnikov is aware of a total of 17 kistens from this area. The 13 lash-balls in the Zaussailov Collection of the National Museum of Finland are precisely from the Bolgar region, more precisely from the government of Kazan. The balls were originally assumed to be weights (Tallgren 1918, 42, Pl. VIII: 31-32). The material includes two examples of Group IIa, one from Anelei in the district of Tsivil'sk (Taavitsainen 1990, 192, Fig. 2) and the other from Boltai in the district of Tetjus (Z. 3397).

Although the Russian kistens are among the oldest European items of this kind, lashes or whips fitted with iron balls were known also in Europe and even in Japan 
(Demmin 1891, 792-796). Some scholars suggest that this weapon was never actually adopted in the Nordic countries; at least it is not mentioned in studies on medieval armament (see e.g. Thordeman 1943). There is, however, a recent find of an eastern kisten decorated with plant ornament from Mainz, Germany (Fig. 6; Wamers 1994, 153, Fig. 90: 246, 154), which belongs to Kirpičnikov's Type III (Fig. 3) and is dated to the first half of the 13th century (Kirpičnikov 1966, 62).

There is yet another Finnish find that may be associated with this group. A curlywood ball discovered in the excavations of the Rettig site in the old centre of Turku has been interpreted as belonging to a lash or whip (Fig. 7a). The object is of uncertain date, but there are numerous medieval finds from the area (Appelgren 1902a and 1902b). Appelgren (1902a) maintained that the round curly-wood ball with iron spikes ..."no doubt belonged to a lash of precisely the same form as shown in Fig. 16 (Fig. 7b). Such lashes were common in the late 15th and early 16th centuries. The find serves to illustrate the brutal customs of the period in punishing or torturing people."

Olaus Magnus describes Finnish customs of warfare and how "some even use fistsized stones attached to ropes four spans long (if they do not have iron or lead balls
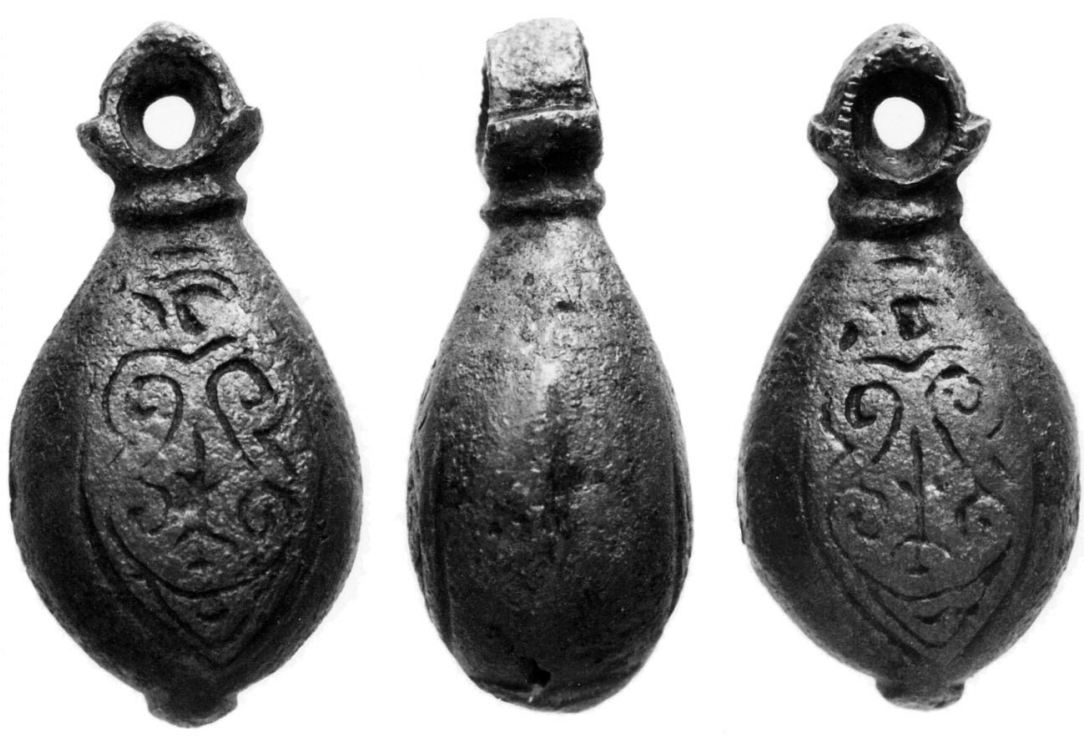

Fig. 6. Kisten with plant ornament found in urban excavations in Mainz, Germany. Length ca. $4 \mathrm{~cm}$. Photo by: Dr. Egon Wamers / Museum für Vor- und Frühgeschichte - Archäologisches Museum / Frankfurt am Main.

Joon 6. Piitsnuia taimornamendiga kaunistatud $4 \mathrm{~cm}$ pikkune munak Mainzist. 

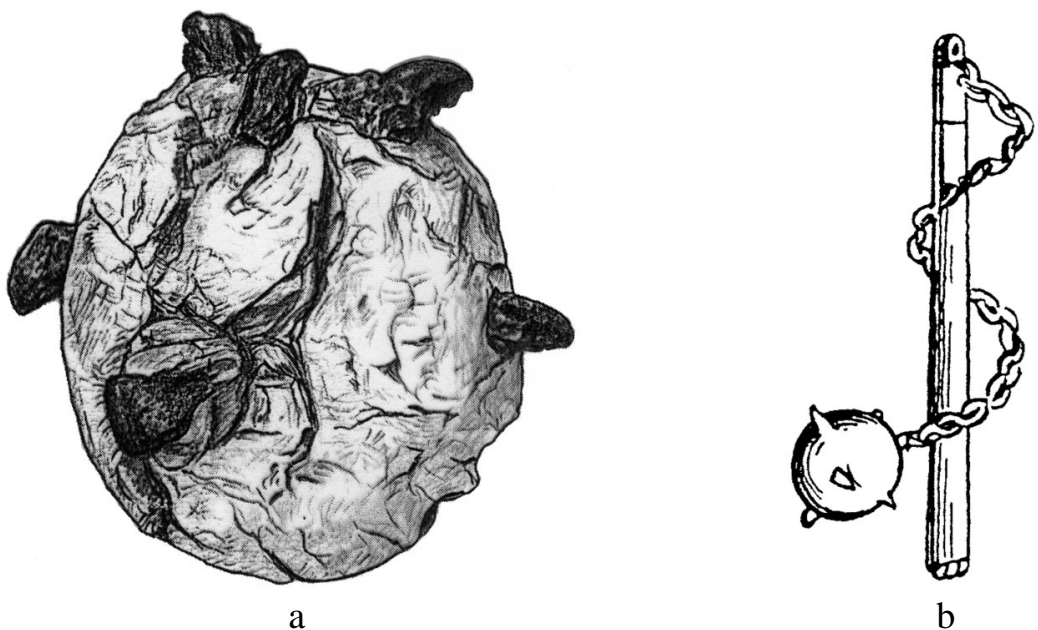

Fig. 7. Curly-wood ball with nails of which the heads were left raised (7a; NM/Historical Collections 4034: 53), which Appelgren (1902a) interpreted as part of a flail similar to illustration 7b.

Joon 7. Naeltega varustatud puust kera (7a), mida Appelgren tõlgendas piitsnuia otsikuna (7b).

and iron chains) which are attached to wooden handles. They are wound around the arms of mounted soldiers or the legs of horses, which are pulled down with a sudden jerk" (Fig. 8; Olaus Magnus 1973, 91-92). Moreover, in presenting various weapons, Olaus Magnus (1976, 6: 3) included the joint flail (Fig. 9). According to this source, at some stage the flails nonetheless belonged to the weapons used in Finland.

The lash-balls from Raisio and Kuhmoinen are both eastern artefacts. The discovery of the latter in the region of Päijät-Häme need not be regarded as unusual. On the other hand, the eastern kisten from Mulli, Raisio is not a typical West Finnish find. It actualizes the problem of the emergence of cultural boundaries and their precise definition.

The area of Late Iron Age settlement in Western Finland has traditionally been regarded as uniform in its material culture, but upon closer inspection it no longer appears to be so integrated as presumed during the Crusade Period (AD 10251200/1300), which is the last prehistoric period in Finland. The Mulli find is precisely from this period, during which burial customs began to change, thus leaving us with ever smaller amounts of finds. Personal ornaments are the most representative and comparable category of finds for outlining the cultural areas of the era as based on material culture. With regard to personal ornaments, the permanently settled area of Finland in fact falls into three parts: Western Finland, Häme and Eastern Finland. The western personal ornaments are characterized by small penannular brooches, while the Savo-Karelia region, oriented towards Novgorod, had its own set of ornaments consisting of oval tortoise brooches and large Karelian penannular brooches. Remaining between these areas is a region where the distributions of 


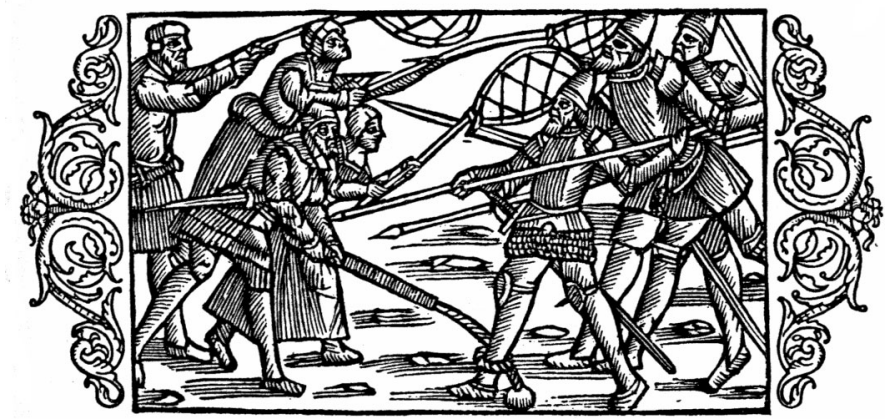

Fig. 8. Describing the Finns' customs of warfare, Olaus Magnus notes how "some even use fist-sized stones attached to ropes four spans long, which are attached to wooden handles. They are wound around the arms of mounted soldiers or the legs of horses, which are pulled down with a sudden jerk" (Olaus Magnus 1973, 91-92).

Joon 8. Kirjeldades soomlaste sõjapidamistavasid, märgib Olaus Magnus: "Mõned kasutavad isegi puust käepidemete külge nelja vaksa pikkuste nahkrihmadega seotud rusikasuurusi kive. Need heidetakse ratsasõdurite käe või hobuse jala ümber, tõmmates need järsu nõksuga maha."

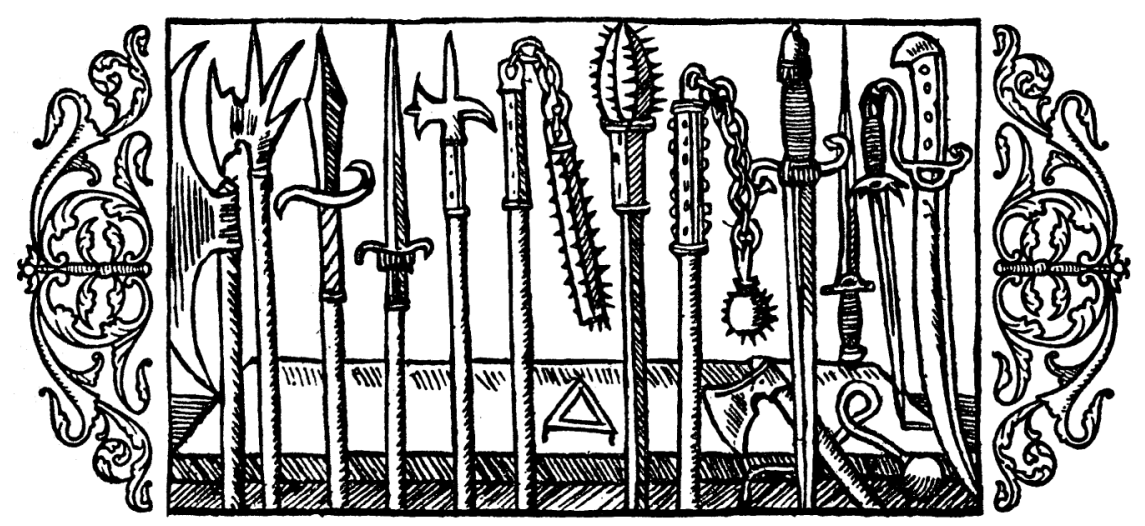

Fig. 9. Illustration from Olaus Magnus (1976, 6: 3) showing weapons used by the northern peoples. Joon 9. Olaus Magnuse joonis, mis näitab põhjala rahvaste kasutatud relvi.

eastern and western personal ornaments intersect, largely corresponding to the historical province of Häme (see Taavitsainen 1990, 77-84, 109-112).

Häme, in turn, is divided into the western Lake Vanaja region and the eastern Päijät-Häme region. In the former area, oval tortoise brooches of both Häme-based and Savo-Karelian distribution have been found. The Päijät-Häme region, however, exhibits the most prominent archaeologically observable eastern influence in Häme. Although the number of finds is small, we must explain the archaeological observation. 
In the region of Lake Päijänne there are also numerous geographically interspersed place names related to Häme, Karjala (Karelia), Venäjä (Russia) or Ruotsi (Sweden) (Suvanto 1986, Vahtola 1980), and the distribution of eastern artefacts is interspersed in the same manner. In fact, this interspersed nature may actually explain the "pattern of sets of personal ornament" of Eastern Häme, which is the result of the presence of West Finnish (small penannular brooches), Lake Vanaja region (oval Häme tortoise brooches and small penannular brooches) and East Finnish ornaments (eastern brooches) in the region. The distribution of the personal ornaments may be explained by the fact that this region was jointly utilized from three different directions.

A map of the northern part of the Päijät-Häme region in the Late Middle Ages (Niitemaa 1955, 399, Fig. 79) shows how this area was utilized from two different areas of personal ornaments; it was the erämark - wilderness of the inhabitants of Sääksmäki (small penannular brooch area) and Hauho (area of the oval Häme tortoise brooches and small penannular brooches). The situation of the period no longer indicates the former Karelian utilization of wilderness resources as indicated by place names. At the transition from prehistoric to historically recorded times, there may have been three different sets of personal ornaments in use in the area. There are historical, place-name-based and dialect-related analogies for the archaeological observation (see Taavitsainen 1994 and 1998).

In light of this information it is also interesting to review a discussion from the close of the last millennium concerning the course of the border laid down in the Treaty of Schlüsselburg (Pähkinäsaari). With reference to the historical analogy of the border treaty between Norway and Novgorod, related administrative procedure and the routines of document-related administration, Jarl Gallén and John Lind suggested that in Southern Lapland the border was bifurcated, with one branch establishing the eastern boundary of Swedish interests and the other branch marking the western limit of Novgorod's interests. The area remaining in between would thus have been available for shared utilization (Gallén 1968; Gallén \& Lind 1991). This view has been sharply criticised (e.g. Kirkinen 1992; 1994; Lind 1993; Vahtola 1993; see, however, e.g. Orrman 1991).

The discussion ignored the archaeological record, which precisely tells of settlement and even of erämark utilization. The composition of finds from the PäijätHäme region, in turn, is a prehistoric analogy for the border suggested by Gallén and Lind (Taavitsainen 1994). If I have understood the argument correctly, Gallén's and Lind's interpretation also finds support in the views expressed by Suvanto and Vahtola.

The eastern-influenced Lake Vanaja region of Häme falls between Western Finland and Karelia. Päijät-Häme, the wilderness or erämark area to its east, was utilized from three different cultural regions during the Crusade Period. It is to this period that the inland hillforts of both this area and the region of Lake Vanaja are dated. It was also a period of sporadic chronicle sources briefly describing warring expeditions from Novgorod and Karelia to Häme, and vice-versa (Taavitsainen 1990, 45-47,127-133). The shared utilization area of Päijät-Häme is chronologically close 
to the time when the Treaty of Schlüsselburg was signed. Why could it not have been possible to take note of shared erämark utilization based on solidly established custom in the northern regions known at the time of the treaty? Pressure from the west appears to have continued and focused possibly on erämark areas that were already known previously in the Iron Age. The purpose of the Treaty of Schlüsselburg was to halt the western expansion or, in any case, regulate it.

The emergence of various cultural boundaries as well as transitional zones of cultural influences have been studied by Finnish ethnologists. Ethnologists active in Turku included Ilmar Talve (e.g. Talve 2000); his pupil Pekka Leimu has also shown professional interest in this subject on a European level. Leimu has discussed and treated the concept of Middle Europe (e.g. Leimu 1998 and 1999) as a zone of transition between the eastern and western cultures, in the same way as Central Europe is a transitional zone between Southern and Northern Europe. Leimu notes that this is not a cultural region as such but a zone of transition between two cultures. With regard to the boundaries of this zone it is not precisely known where they begin or end.

The Mulli find is related precisely to the time when the boundary of the eastern and western churches began to form in Europe; discussion of what this may have been based on is not a subject of this article. Only a few eastern objects of the Late Iron Age are known from Southwestern Finland. ${ }^{1}$ We must also bear in mind that finds cannot always be defined unequivocally as eastern (see Taavitsainen 1990, 81, note 30). It is also difficult to clearly define the borders of the above-discussed three late prehistoric zones of material culture or boundaries within Häme. But these cultural areas are in fact transitional zones with moving boundaries situated between Western and Eastern Europe.

The eastern finds, however, do not characterize the material culture of Southwestern Finland. For example, in the valley of the River Vähäjoki in Maaria there are 11 Crusade Period settlement units (Saloranta 1994, 29, Appendix 3.1), from which only one possible eastern bracelet (from Virusmäki in Maaria) and a possible eastern crucifix from Taskula in Maaria have been found. In relative terms, this is an extremely small number, considering the large number of cemeteries in the region. This is further underlined by the fact that the numerous stray finds from the river valley do not include a single eastern artefact. The Mulli find and the other few finds representing the eastern cultural region, however, are a reminder of how difficult it can be to define the boundaries of cultural regions: all borders leak, in regions

1 Karelian oval tortoise brooches: Vaskio, Halikko (C2 brooch); Luolavuori, Turku (F brooch, NM/ Prehist. 23586). Crucifixes: Haimionmäki, Lieto (NM/Prehist. 13705:158); Taskula, Maaria (Turku Provincial Museum 1350:126). Eastern chain-bearers: Rikala, Halikko, grave $\AA$ ( 2 pcs., NM/Prehist. 12690:394-395); Yliskylä, Perniö, Grave II (3 pcs., NM/Prehist. 2912:74). Eastern bracelets: Virusmäki, Maaria (NM/Prehist. 6649:3); Rikala, Halikko (NM/Prehist. 12481:2).

Place names of eastern origin in the Turku region are referred to occasionally, but toponymy is not discussed here. The onomastic views suggested by archaeologists have not always been relevant anyway. 
and Europe alike. The "filters" of the Päijät-Häme and Lake Vanaja regions passed eastern artefacts even further west. It may sometimes be difficult to remember this fact if one belongs to the generation for whom the concept of a border was equivalent to the Berlin Wall or the border between Finland and the Soviet Union. Yet, as recent events have shown, even that border was not impenetrable.

\section{Acknowledgements}

The excavations in Raisio were supported by the City of Raisio and the Southwestern Finland Fund of the Finnish Cultural Foundation. The English translation of this article was made possible by support from the Academy of Finland.

\section{References}

Alén, V. 1998. Miekasta nuppineulaan. Kaivausmetodimuutosten yhteys esinelöytöihin kirkkokaivauksissa 1960-1980-luvuilla. Graduate thesis on excavation methods in church excavations from the 1960s to1980s. Archaeology/University of Turku.

Alén, V. 2001. Från svärd till knappnålar. Relationen mellan nya grävningsmetoder och föremålsfynd i utgrävningen av några kyrkor på 1960-1980-talen. - Meta, 2001: 1, 13-23.

Antell, A.-C. 1998. Savikiekkojen ensisijainen ja toissijainen käyttö Mullin asuinpaikalla (n. 9801220). Graduate thesis on the primary and secondary use of clay discs at the Mulli site. Archaeology/ University of Turku.

Appelgren, H. 1902a. Maanalainen Turku. - Uusi Aura, 44-53/22.2.-5.3.

Appelgren, H. 1902b. Det underjordiska Åbo. - Finskt Museum, 1901, 49-65.

Artem'ev, A. R. 1990. Kisteni i bulavy raskopok Novgoroda Velikogo. - Materialy po arheologii Novgoroda, 5-28.

Brusila, H. 1992. Muinaisesta Raisiosta. Raisio.

Demmin, A. 1891. Die Kriegswaffen in ihren geschichtlichen Entwickelungen von den ältesten Zeiten bis auf die Gegenwart. Leipzig.

Díaz, L. 1998a. Digital archaeology: Design research and education - Connecting Historical Narratives and Digital Environments. - Leonardo, 31: 4, 283-287.

Díaz, L. 1998b. Can the muses be revived? Futurefusion. - Application Realities for the Virtual Age. Volume One. 4th International Congress on Virtual Systems and Multimedia. Ed. by Hal Twaites, Gitu University, Japan.

Díaz-Kommonen, L. 2002. Art, Fact and Artifact Production. Design Research and Multidisciplinary Collaboration. (Publication series of the University of Art and Design Helsinki, A 37.)

Gallén, J. 1968. Nöteborgsfreden och Finlands medeltida östgräns. (Skrifter utgivna av Svenska litteratursällskapet i Finland, 427: 1).

Gallén, J. \& Lind, J. 1991. Nöteborgsfreden och Finlands medeltida östgräns. (Skrifter utgivna av Svenska litteratursällskapet i Finland, 427, 2-3.)

Gorelik, M. 1993. Voiny kievskoj Rusi IX-XI vv. - Cheigaus, 1/93(2): 20-25.

Harjula, J. (teksti) \& Ermala, Y. (piirrokset). 1997. Raision vaskipolku. Matkalle tuhannen vuoden taakse. Raision kulttuuritoimi. (Vaskipolkuesite.)

Hiekkanen, M. 2003. Suomen kivikirkot keskiajalla. Keuruu. 
Hirviluoto, A.-L. 1973. Raision Ihalan Avaskivaipat. - Honos Ella Kivikoski. (SMYA, 75, 60-67.) Jäkärä, T. 1997a. Turun Kirkkomäen ja Raision Ihalan Kansakoulun kalmistojen hautarakenteet. Graduate thesis on burial structures in the cemeteries of Kirkkomäki, Turku and Ihala, Raisio. Archaeology/University of Turku.

Jäkärä, T. 1997b. Ruumisarkuissa käytetyistä puulajeista. - SKAS, 1.

Jäkärä, T. 1998. Tutkimuskohteena hautarakenteet - esimerkkinä kaksi varsinaissuomalaista kalmistoa ristiretkiajalta. - Muinaistutkija, 2, 2-5.

Kirkinen, H. 1992. Mikä oli Pähkinäsaaren rauhan raja? - Historiallinen Aikauskirja, 4, 304-318.

Kirkinen, H. 1994. Pohjanlahti vai Vienan meri 1323? - Historiallinen Aikakauskirja, 1, 42-47.

Kirpičnikov, A. N. 1966. Drevnerusskoe oružie, 2. (Arheologija SSSR E1-36.)

Kirpičnikov, A. N. 1976. Voennoe delo na Rusi v XIII-XV vv. Leningrad.

Laakso, M. 1998. Turun keskiaikaisen keramiikan karakterisointi ja luokittelu petrofysikaalisin menetelmin. Graduate thesis on the characterization and classification of medieval ceramics from Turku with petrophysical methods. Quaternary geology/University of Turku.

Lavento, M. \& Suhonen, M. 2003. Arkeologinen hypermedia: taidetta, tosiseikkoja, artefaktituotantoa. - Muinaistutkija, 1, 40-46.

Lehtonen, S. 2003. Raision Mullin keramiikka. Graduate thesis on ceramics from the Mulli site in Raisio. Archaeology/University of Turku.

Leimu, P. 1998. European cultural boundaries and Middle Europe. Paper at the second EUxIN seminar, Turku 18.12.1998.

Leimu, P. 1999. 'Middle Europe' as a multidisciplinary concept. - Preprint 10/1999. L'Europa delle idee Cultura europea e tradizioni nazionali. Atti del seminario EUxIN, Bologna, 5 febbraio 1999 a cura di Giuliano Pancaldi con il contributo della Commissione Europea, DG X, 73-80.

Lind, J. 1993. Pähkinänsaaren rauhansopimuksen ruotsinkielinen teksti ja kaksihaarainen raja. Historiallinen Aikakauskirja, 2, 157-162.

Mäesalu, A. 1998. Turun yliopiston arkeologian oppiaineessa pidetyn luentosarjan Keskiajan aseet ja niiden kehitys 1200-1550 tekstin valokopio. J.-P. Taavitsaisen hallussa. Photocopy of lecture text in the possession of J.-P. Taavitsainen.

Niitemaa, V. 1955. Hämeen keskiaika. - Hämeen historia, I, 199-541.

Näränen, J. 2000. Maahan kätketty menneisyys. - Kosminen lintu. Eero Rantasen Taidekokoelmien ystävät ry:n lehti, 3, 10-11.

Näränen, J. \& Heikkinen, T. 2000. Vuosituhansien taa. Raision esihistorian pääpiirteet. (Raision kaupungin kulttuuritoimen julkaisuja, 1.)

Olaus Magnus Gothus. 1973. Pohjoismaisten kansojen historia. Suomea koskevat kuvaukset. Helsinki.

Olaus Magnus Gothus. 1976. Historia om de nordiska folken. Stockholm.

Orrman, E. 1991. Jarl Gallénin vieroksuttu rajateoria saa tukea tanskalaistutkijalta. Pähkinänsaaren rauha määritti Ruotsin ja Novgorodin yhteismaat. - Helsingin Sanomat, 9.11.1991, B6.

Pihlman, A., Pihlman, S. \& Taavitsainen, J.-P. 2001. Kylästä kaupungiksi. Från by till stad. Museotiedote Turusta. Museinytt från Åbo, 3, 11-13.

Pihlman, S. (text) \& Ermala, Y. (illustrations). 1997. 1000 vuotta sitten Raisiossa. Arkeologinen näyttely Krookilan kotiseutukeskuksessa 18.6.-5.9.1997. Raision kulttuuritoimi (Exposition).

Pihlman, S. 2000. Miten arkeologia tuli ja jäi Raisioon. - Vuosituhansien taa. Raision esihistorian pääpiirteet (ed. by Jari Näränen \& Titta Heikkinen). (Raision kaupungin kulttuuritoimen julkaisuja, 1.)

Saloranta, E. 1994. Rautakautinen kolonisaatio ja maankäyttö Turun (Maarian) Vähäjokilaaksossa. Graduate thesis on Iron Age colonization and land use in the valley of the River Vähäjoki in Turku (Maaria). Archaeology/University of Turku. 
Siiro, P. 1998. Raision Mullin myöhäisrautakautisen/varhaiskeskiaikaisen asuinpaikan sedimentit ja kulttuurisiitepölyt. Graduate thesis on the sediments and cultural pollen material of the Mulli site in Raisio. Quaternary geology/University of Turku.

Spoof, L. 2001. Raision ja Ruskonjokilaakson asutuksen kehitys rautakaudelta historialliseen aikaan ja luonnonolojen vaikutus sen muotoutumisessa. Graduate thesis on the history of settlement in Raisio and the valley of the River Ruskonjoki from the Iron Age to historically documented times and the effect of natural conditions on its formation. Archaeology/University of Turku.

Suhonen, M. 1998. A lead-bronze ingot from Mulli at Ihala in Raisio. - Fennoscandia archaeologica, $\mathrm{XV}, 71-75$.

Suhonen, M. 2000a. Stratigrafinen kaivaustapa metodisena kokeiluna Raision Ihalan Mullin myöhäisrautakautisen/varhaiskeskiaikaisen asuinpaikan kaivauksella vuosina 1995-1997. Graduate thesis on stratigraphic excavation as a methodological experiment in the excavations of the Mulli site in Raisio, 1995-1997. Archaeology/University of Turku.

Suhonen, M. 2000b. Stratigraphic excavation method at a prehistoric site Raisio Ihala Mulli: A Finnish pioneer project. - Att tolka stratigrafi. Det tredje nordiska stratigrafimötet Åland 1999. (Meddelanden från Ålands högskola, 11, 69-79.)

Suhonen, M. \& Vuorinen, J.-M. 1997. Bonden Paavo Raision Mullissa. - SKAS, 3, 8-13.

Suvanto, S. 1986. Ruotsin ja Venäjän raja Suomessa ennen Pähkinäsaaren rauhaa. - Historian Arkisto, $88,49-65$.

Taavitsainen, J.-P. 1990. Ancient Hillforts of Finland. Problems of Analysis, Chronology and Interpretation with Special Reference to the Hillfort of Kuhmoinen. (SMYA, 94.)

Taavitsainen, J.-P. 1994. Östra Tavastland som samfälld erämark. - Historisk tidskrift för Finland, 3, 391-412.

Taavitsainen, J.-P. 1998. Itäinen Häme yhteisnautinta-alueena - piirteitä Päijänteen alueen myöhäisrautakautisesta historiasta. - (Päijänne suomalainen suurjärvi.) (Toim. L. Hakkari ja S. Saukkonen). Jyväskylän yliopisto/Ympäristötieteet, Jyväskylä seura ry, Päijänne-luontokeskus. Jyväskylä, 65-76. Tallgren, A. M. 1918. Collection Zaoussaïlov au museé national de Finlande a Helsingfors II. Monographie de la section de l'age fer et l'époque dite de Bolgary. Helsingfors.

Talve, I. 2000. Europas folk. Åbo: Fortbildningscentralen vid Åbo Akademi.

Thordeman, B. 1943. Vapnen i Nordens forntid. Vapen. - Nordisk kultur, XII: B, 1-66.

Tupala, U. 1999. Raision Mullin rautakautisen asuinpaikan ja Euran Luistarin rautakautisen ruumiskalmiston eläinluuaineiston vertailu. Graduate thesis on comparisons of animal bones from the Iron Age Mulli site in Raisio and the Iron Age inhumation cemetery of Luistari in Eura. Archaeology/ University of Turku.

Vahtola, J. 1980. Tornionjoki- ja Kemijokilaakson asutuksen synty. Nimistötieteellinen ja historiallinen tutkimus. (Studia historica septenrionalis, 3.)

Vahtola, J. 1993. Pitkästä aikaa suomenruotsalainen yleisesitys Suomen historiasta (arv. Torsten Edgren \& Lena Törnblom: Finlands historia 1. Schildts. Ekenäs 1993. 437 s.). - Historiallinen Aikakauskirja, 4, 333.

Wamers, E. 1994. Die frühmittelalterlichen Lesefunde aus der Löhrstrasse (Baustelle Hilton II) in Mainz. (Mainzer Archäologische Schriften, 1.)

Vuorinen, J.-M. 1997. Rakentamisesta Raision Mullissa rautakauden lopulla ja keskiajalla. - Muinaistutkija, 45-48.

Vuorinen, J.-M. 2003a. Rakennukset sosiaalisen toiminnan näyttämönä. Rakentaminen Raision Ihalan Mullissa rautakauden lopulla ja varhaisella keskiajalla. Licentiate thesis on buildings as scenes of social activities with reference to building and construction at the Mulli site in Raisio at the end of the Iron Age and in the Early Middle Ages. Archaeology/University of Turku.

Vuorinen, J.-M. 2003b. Hallitalo ja hirsirakennus - elämää ahtaassa asumuksessa mutta väljässä pihapiirissä. - Muinainen Kalanti ja sen naapurit. Talonpojan maailma rautakaudelta keskiajalle (ed. by V. Kaitainen, E. Laukkanen \& K. Uotila). Helsinki, 185-198. 


\section{Jussi-Pekka Taavitsainen \\ RAISIO MULLI PIITSNUIA MUNAK - KESK-EUROOPA ILMING EDELA-SOOMES}

\section{Resümee}

Artiklis tutvustatakse Turu Ülikooli arheoloogia õppetooli Raisio projekti, mis hõlmab nii aastail 1994-1997 tehtud väljakaevamisi Mullis kui ka varasematel aegadel Raisio kihelkonnas läbi viidud välitöid (eelkõige kalmete uurimisi). Kesksel kohal on olnud ühe Lääne-Soome erakordselt hästi säilinud asulakoha ehitusjäänused 11.-13. sajandist. Projektiga seotud arvukad uurimused jagunevad kolme rühma: metodoloogilised, asustusarheoloogilised ja sotsiaalmajanduslikud. Lisaks nendele on avaldatud ka üksikküsimusi ja üksikleide käsitlevaid artikleid.

Üheks erakordseks leiuks Mulli asulakohalt oli pirni- või sibulakujuline pronksist munak, mis on varustatud kinnitusaasaga. Eseme pikkus on 6,4 ja laius 3,6 cm, kaal $110 \mathrm{~g}$ (joon 1). Tegu on koodisarnasel põhimõttel kasutatava nn piitsnuia otsiku või munakuga. Selline relv, mis koosnes puust käepidemest ning selle külge nahkrihmaga seotud metallkerast, oli üsna tavaliseks sõjariistaks varakeskaegsel Venemaal. Seal nimetati neid nuiasid kisteniteks ja kasutati nii jala- kui eriti just ratsaväes (joon 2). A. Kirpitšnikovi järgi kasutasid piitsnuiasid Volga- ja Doni-äärsed rändrahvad juba I aastatuhande teisel poolel. Venelased võtsid relva üle 10. sajandil, kusjuures Mulli eksemplariga kõige enam sarnanevad Vene leiud on dateeritud 13. sajandisse.

Soomes tuntakse veel üht piitsnuia otsikut - see leiti Kuhmoineni linnamäelt ja kuulub 12.-13. sajandisse (joon 3). Kolmas kõnealust tüüpi ese pärineb Turu vana keskuse 15.-16. sajandi kihtidest (joon 7a). Et Soomes on piitsnuiasid laialdasemalt kasutatud, selgub ka Olaus Magnuse kirjeldusest soomlaste keskaegsete võitlusviiside kohta.

Mulli piitsnuia kasutamise aegadel võttis kindlamaid jooni Euroopa jagunemine kahe kiriku, roomakatoliku ja õigeusu, lääne ja ida vahel. Soomes võib ristiretkede aja (1025-1200/1300) materiaalse kultuuri, eriti ehtekunsti alusel eristada kolme kultuurivaldkonda: Lääne-Soome, Ida-Soome ja Häme. Lääne-Soomes võib kohata vaid üksikuid idapoolse päritoluga esemeid, millest üks ongi artiklis käsitletud Mulli piitsnui. Hämes leidub tooteid nii ida kui ka lääne poolt. Samas on piire kolme kultuuriareaali vahel raske täpselt määratleda, pigem on tegu pidevalt muutuvate siirdevöönditega Ida- ja Lääne-Euroopa vahel. Need ei olnud Berliini müüri taolised ületamatud piiritõkked, vaid toimisid eeskätt nn kultuurifiltritena, mille piiride kohta pole kunagi teada, kus need algavad ja kus lõpevad. 